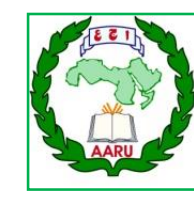

Arab Univ. J. Agric. Sci., Ain Shams Univ., Cairo, Egypt 29(2), 645-654, 2021

Website: http://ajs.journals.ekb.eg

DOI: 10.21608/ajs.2021.75205.1375

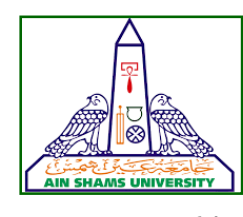

645

\title{
Effect of Palm Kernel Cake and Probiotics on Growth Performance of Growing Barki Lambs
}

\author{
Hend A Sayed ${ }^{*}$, Hany M Gado', Ahmed AM Abdelhafez ${ }^{2}$, \\ Hamdy M Metwally ${ }^{1}$
}

1- Animal Production Dept, Fac of Agric, Ain Shams Univ, P.O. Box 68, Hadayek Shoubra 11241, Cairo, Egypt

2- Agric Microbiology Dept, Fac of Agric, Ain Shams Univ, P.O. Box 68, Hadayek Shoubra 11241, Cairo, Egypt

*Corresponding author: hendas1982@gmail.com

Received 4 May, 2021

Accepted 12 June, 2021

Abstract
The effect of two probiotic products with
Palm Kernel Cake (PKC) as source of dietary
protein and/or energy in ruminant diets on the
growth performance and some blood parame-
ters of Barki lamps were evaluated. Two com-
mercial probiotic formulas (ZAD and ICEC-
Trol) were administrated directly with theirap-
plications: P1 (without probiotic), P2 (ZAD),
P3 (ZAD + ICEC-Trol), the combination of
four different rations: R1 (control), R2 (PKC
as source of energy), R3 (PKC as source of en-
ergy and protein) and R4 (PKC as source of
protein). Barki lambs (n=96, 35kg average
body weight) were randomly assigned to 12
experimental groups in a completely random-
ized block design. ( 8 lambs for each group)
and fed for 47 days. ZAD probiotic was ap-
plied at 2 ml/head/day and ICEC-TROL was
applied at 3 g/head/day. Animals weight gain
and average daily gain were measured and
Glucose, total protein, albumin, calcium and
phosphorus were measured. Results showed
that animals fed control ration (R1) with P2,
R2 with P3 and R4 with P3 showed highest
(P<0.05) total weight gain (10.75, 10.88 and
10.56 , respectively) and average daily gain
(0.229, 0.231 and 0.225, respectively). ZAD

probiotic improved serum total protein, globulin, glucose when using with PKC in lambs' rations. In conclusion, using $\mathrm{PKC}$ as a source of energy or protein, with two sources of probiotics in lambs' rations showed to be more effective in weight gain, while using one probiotic (ZAD) is enough for fattening with traditional rations.

Keywords: Probiotic, PKC (Palm Kernel Cake), ruminants

\section{Introduction}

The byproduct of extracting Palm kernel oil from ground Palm kernels is PKC (PKC) (Kum and Zahari 2011). Among all by-products from oil Palm plantation, PKC was the most widely studied and has been used in animal feeding. Although the fiber content of PKC could be relatively high especially when contaminated by nutshell, basically this byproduct could be classified as non-fibrous ingredient for animal feed (Ginting et al 2018). Close examination of PKC has revealed that it can be classified as a protein feed, since it contains about $16 \%-18 \%$ protein, $\mathrm{PKC}$ 's limiting amino acid content is usually lysine, then sulphur amino acids (methionine, cysteine), and tryptophan. (Alimon 2004). Furthermore, PKC 
is classified as energy feed because it has relatively high oil content, averaging $10 \%$, making it a good source of metabolizable energy for feed applications. (Sue 2004), and its average energy value may reach to $2506 \mathrm{Kcal} \mathrm{ME} / \mathrm{Kg}$ DM (Ginting et al 2018). The crude fiber content of $\mathrm{PKC}$ is accepted by most ruminants and ranges between $16 \%$ and $18 \%$. Analysis shows that more than $60 \%$ of PKC is a component of the cell wall (Alimon 2004). The majority of the component of fibers is made up of insoluble mannose-based polysaccharides (mannan). According to Jaafar and Jarvis (1992), the cell wall of PKC consists of $58 \%$ mannan, $12 \%$ cellulose, and $4 \%$ xylan.The majority of research on PKC in ruminant diets has focused on replacing grain with PKC (Iqbal et al 2019). Several treatments have been suggested to improve the nutritional value of $\mathrm{PKC}$, including physical treatment and addition of probiotics and enzyme (Marini et al 2005, Saenphoom et al 2011, Alshelmani et al 2014, Roslan et al 2017). Probiotics are live microorganisms that, when consumed in adequate amounts, can provide health advantages to their hosts (Kim et al 2007). Biological treatment is an innovative method for improving the nutritional value of lignocellulosic materials of crop residues (Gado and Salem 2013). A probiotic is a feed additive that improves the intestinal microbial balance of the host animal, Then modify the rumen fermentation and optimize the performance of the animal production system (Gadekar et al 2015, Gado 2020). Also, probiotics has extensive importance for improvement of nutrient utilization (Soren et al 2013), as well as animal growth and production (Ganai et al 2015).

As a result, the purpose of the present study was to observe how feeding PKC with one of two different probiotics affects the growth of ruminants and certain blood parameters.

\section{Materials and Methods}

\subsection{Probiotics}

Two probiotics products were used in this study: ZAD (mixture of anaerobic probiotic bacteria and exogenous enzymes) and ICECTROL (commercial growth promoter, composed of Saccharomyces cerivisiae, Bacillus subtilis, Streptococcus faecium, Lactic acid bacteria, Mannan Oligosaccharides and $\beta 1.3$, 1.6 D-Glucan carried on wheat bran).

\subsection{Ration and Feeding}

Total of 96 Barki lambs with an average live weight of $35 \mathrm{~kg}$, were used in this study. The experimental period consisted of 15 days of ration adaptation followed by 47 days for feeding, data and sampling collection. The animals were divided randomly into 12 groups (8 lambs in each group), as follows:

Group (1) was fed R1 without probiotic,

Group (2) was fed R2 without probiotic,

Group (3) was fed R3 without probiotic,

Group (4) was fed R4 without probiotic,

Group (5) was fed R1 with ZAD (2 $\mathrm{ml} /$ head/day),

Group (6) was fed R2with ZAD (2 $\mathrm{ml} /$ head/day),

Group (7) was fed R3 with ZAD (2 $\mathrm{ml} /$ head/day),

Group (8) was fed R4 with ZAD (2 $\mathrm{ml} /$ head/day),

Group (9) was fed R1, $\operatorname{ZAD}(2$ $\mathrm{ml} /$ head/day)and ICEC-Trol (3 g/head/day), Group (10) was fed R2, ZAD (2 $\mathrm{ml} / \mathrm{head} /$ day)and ICEC-Trol (3 g/head/day), Group (11) was fed R3, ZAD (2 $\mathrm{ml} / \mathrm{head} /$ day)and ICEC-Trol ( $3 \mathrm{~g} / \mathrm{head} /$ day), Group (12) was fed R4, ZAD (2 $\mathrm{ml} /$ head/day)and ICEC-Trol (3 g/head/day). 


\section{Effect of Palm Kernel Cake and Probiotics on Growth Performance of Growing Barki Lambs}

Probiotic additives were added to the meal directly before feeding. Animals were fed twice a day, and water was available for drinking at all times of the day. Total mixed ration ingredients and the chemical composition of basal experimental ration is presented in Table 1 and Table 2, animals were weight every 15 days.

\subsection{Chemical analysis}

Chemical analysis of total mixed rations (TMR) and its components were carried out to determine $\mathrm{DM}, \mathrm{CP}, \mathrm{EE}, \mathrm{CF}$ and Ash contents according to the methods of AOAC (1995). Fiber fraction was determined according to Van Soest et al (1991). Total mixed ration (TMR) of experimental rations were presented in Table $\mathbf{1}$ and chemical analysis presented in Table 2.

Table 1. Total mixed ration ingredients (\%)

\begin{tabular}{|c|c|c|c|c|}
\hline Ingredient & R1 & R2 & R3 & R4 \\
\hline Yellow Corn & 49.8 & --- & --- & 24.95 \\
\hline Sunflower meal & 8.8 & 8.8 & --- & --- \\
\hline PKC (PKC) & --- & 50 & 58.8 & 24.95 \\
\hline Alfa Alfa & 39.9 & 39.9 & 39.9 & 48.7 \\
\hline Salt & 0.8 & 0.8 & 0.8 & 0.8 \\
\hline Minerals & 0.3 & 0.3 & 0.3 & 0.3 \\
\hline Urea & 0.3 & 0.1 & 0.1 & 0.2 \\
\hline Molasses & 0.1 & 0.1 & 0.1 & 0.1 \\
\hline Total & 100 & 100 & 100 & 100 \\
\hline
\end{tabular}

Table 2. Chemical composition (\%)of total mixed ration(TMR) used in the experiment

\begin{tabular}{|c|c|c|c|c|}
\hline $\begin{array}{l}\text { Chemical } \\
\text { composition }\end{array}$ & R1 & R2 & R3 & R4 \\
\hline DM & 89 & 89.2 & 88.8 & 88.8 \\
\hline CP & 13.6 & 14.6 & 14.7 & 14.6 \\
\hline CF & 22.5 & 23 & 23.3 & 24 \\
\hline EE & 1.7 & 1.3 & 1.4 & 1.6 \\
\hline Ash & 7 & 7.4 & 7.2 & 7.2 \\
\hline NDF & 38 & 39 & 39.3 & 38 \\
\hline ADF & 30 & 31 & 32.2 & 31 \\
\hline GE & 3608 & 3620 & 3620 & 3640 \\
\hline
\end{tabular}

\subsection{Blood sampling and analysis}

In all treatments, blood samples were collected from 3 animals of each group. Sample of $5 \mathrm{ml}$ of blood per animal was collected from the jugular vein before feeding and after 3 and 6 hours from feeding. Blood samples were collected directly into a dry, clean tube and left to coagulate, then were centrifuged at $10000 \mathrm{rpm}$ for $10 \mathrm{~min}$ to separated blood serum into a clean dried $1 \mathrm{ml}$ Eppendorf tubes and stored at $\left(-20^{\circ} \mathrm{c}\right)$ deep freeze for subsequent chemical analysis.

Glucose, total protein, albumin, calcium and phosphorus were measured calorimetrically with special kits from Biodiagnostic, Dokki, Giza, Egypt. Globulin was calculated by subtracting albumin from total protein and dividing albumin by globulin to get the $\mathrm{A} / \mathrm{G}$ ratio.

\subsection{Statistical analysis}

Data obtained from animal growth performance were subjected to statistical analysis two-way ANOVA of Statistical Analysis using SPSS Software (version 20). Significant differences $(\mathrm{P}<0.05)$ between treatments were determined using analysis of variance and Duncan's multiple range tests. The differences among treatment groups were estimated using the following model:

$$
Y i j=\mu+R_{i}+P_{j}+R P_{i j}+e_{i j k}
$$

Where, Yij: dependent variable, $\mu$ : overall mean, $R_{i}$ : The effect of ration, $P_{j}$ : The effect of probiotic, $\mathrm{RP}_{\mathrm{ij}}$ : interaction between ration and probiotic, and $\mathrm{e}_{\mathrm{ij}}$ : experimental error.

Data obtained from blood parameters were subjected to statistical analysis three-way ANOVA of Statistical Analysis using SPSS Software (version 20). Significant differences $(\mathrm{P}<0.05)$ between treatments were determined using analysis of variance and Duncan's multiple range tests. The differences among treatment groups were estimated using the following model: 
$Y i j=\mu+R_{i}+P_{j}+T_{k}+R P_{i j}+R T_{i k}+P T_{j k}+$ $R P T_{i j k}+e_{i j K}$

Where, Yij: dependent variable, $\mu$ : overall mean, $R_{i}$ : The effect of ration, $P_{j}$ : The effect of probiotic, $\mathrm{T}_{\mathrm{k}}$ : the effect of sampling time $\mathrm{RP}_{\mathrm{ij}}$ : interaction between ration and probiotic, $\mathrm{RT}_{\mathrm{ik}}$ : interaction between ration and sampling time, $\mathrm{PT}_{\mathrm{jk}}$ : interaction between probiotic and sampling time, $\mathrm{RPT}_{\mathrm{ijk}}$ : interaction between ration, probiotic and sampling time, and $\mathrm{e}_{\mathrm{ij}}$ : experimental error.

\section{Results and Discussion}

\subsection{Effect of treatments on growth perfor- mance}

The effect of ration and probiotic treatments on animal weight gain was evaluated. Results in Table 3 showed that ration as main effect and interaction between ration and probiotic had no significant effect on growth performance of lambs. On the other hand, the effect of probiotic on final body weight was significant $(\mathrm{P}<0.05)$ where the combination of ZAD with ICEC-Trol caused the highest value $(44.87 \mathrm{~kg})$. However, there was no significant difference for the effect of ZAD alone (44.33 $\mathrm{kg}$ ) or the combination of both probiotics.

Table 3. Effect of probiotics on lambs' final body weight $(\mathrm{Kg})$

\begin{tabular}{|c|c|c|l|}
\hline Probiotic Ration & N & Mean & SEM \\
\hline P1 & 32 & $42.93^{\mathrm{b}}$ & 0.54 \\
\hline P2 & 32 & $44.33^{\mathrm{ab}}$ & 0.54 \\
\hline P3 & 32 & $44.87^{\mathrm{a}}$ & 0.54 \\
\hline
\end{tabular}

1 P1: control, P2: ZAD, P3: ZAD+ICEC-Trol

2 Different letters indicate significant differences at $\mathrm{p}<0.05$

The interaction between ration and probiotic showed significant effect on total weight gain of experimental animals. Data in Table 4 showed that R1 with P2, R2 with P3 and R4 with P3 had the highest total weight gain (10.75, 10.88 and $10.56 \mathrm{~kg}$, respectively). On the other hand, P1 with all rations had the lowest values of total weight gain.

Similarly, the interaction between ration and probiotic showed significant effect on average daily gain, Table 5, indicated that R1 with $\mathrm{P} 2, \mathrm{R} 2$ and $\mathrm{R} 4$ with $\mathrm{P} 3$ had the highest total average daily gain $(0.229,0.231$ and $0.225 \mathrm{~kg}$, respectively) On the other hand P1 with all rations had the lowest values of total weight gain.

Statistical analysis showed significant effect of interaction between ration and probiotic on total gain initial weight ratio, results in Table 6 indicated that R1 with P2, R2 with P3 and R4 with P3 had the highest total gain initial weight ratio $(31.19,31.64$ and $31.18 \%$ respectively) On the other hand P1 with all rations had the lowest values of total gain initial weight ratio.

In the present study, the rations were suggested to evaluate the effect of PKC with probiotics, as source of protein or/and energy in ruminants' diet, on average daily gain and total weight gain. Results showed that using PKC as a source of energy or protein tended to improve average daily gain and total weight gain in lambs. The inclusion of PKC in lambs rations (R2, R3, R4) increased average daily gain (ADG) by approximately 5.5\% (0.182, 0.183 , $0.182 \mathrm{~g} / \mathrm{d}$, respectively) compared with control group (R1, $0.172 \mathrm{~g} / \mathrm{d}$ ). Even though rations containing PKC had higher weight gain even if rations containing $\mathrm{PKC}$ with corn or sunflower meal (R2, R4) showed more weight gain at addition probiotics to the rations. that is consistent with Saeed et al (2018) reported that inclusion of $10 \%$ corn as a source of energy and 65.3\% PKC as a fattening diet had a positive effect on Dorper lamb growth, ADG, and organ performance. Our findings were consistent with those of Santos et al (2016), who It was found that using PKC as a partial substitute for the concentrate can reduce the intake of most nutrients except EE and NDF and feeding lamb at a ratio of 50:50 fiber/concentrate has a negative impact on digestibility and nutrient performance. Differences among experimental groups in weight gain and ADG are presented 

of Growing Barki Lambs

Table 4. Effect of interaction between probiotic and rations in total weight gain

\begin{tabular}{|c|c|c|c|c|c|c|}
\hline & \multicolumn{4}{|c|}{ Total weight gain $(\mathrm{kg})$} & \multirow[b]{2}{*}{ Mean } & \multirow[b]{2}{*}{ SEM } \\
\hline & R1 & $\mathbf{R 2}$ & $\mathbf{R 3}$ & R4 & & \\
\hline $\mathrm{P} 1$ & $8.06^{\mathrm{e}}$ & $8.56^{\mathrm{de}}$ & $8.63^{\text {cde }}$ & $8.56^{\mathrm{de}}$ & $8.45^{\mathrm{b}}$ & 0.16 \\
\hline $\mathrm{P} 2$ & $10.75^{\mathrm{a}}$ & $9.19^{\mathrm{bcd}}$ & $9.63^{b}$ & $9.25^{\mathrm{bc}}$ & $9.70^{\mathrm{a}}$ & 0.16 \\
\hline P3 & $9.52^{\mathrm{b}}$ & $10.88^{a}$ & $9.50^{\mathrm{b}}$ & $10.56^{\mathrm{a}}$ & $10.12^{\mathrm{a}}$ & 0.16 \\
\hline Mean & 9.45 & 9.54 & 9.25 & 9.46 & & \\
\hline SEM & 0.19 & 0.19 & 0.19 & 0.19 & & \\
\hline
\end{tabular}

1 Different letters indicate significant differences at $\mathrm{p}<0.05$

Table 5. Effect of interaction between probiotic and rations in average daily gain $(\mathrm{kg})$

\begin{tabular}{|c|c|c|c|c|c|c|}
\hline & \multicolumn{4}{|c|}{ Average daily gain } & \multirow[b]{2}{*}{ Mean } & \multirow[b]{2}{*}{ SEM } \\
\hline & R1 & $\mathbf{R 2}$ & R3 & R4 & & \\
\hline $\mathrm{P} 1$ & $0.172^{\mathrm{f}}$ & $0.182^{\text {ef }}$ & $0.183^{\text {cef }}$ & $0.182^{\mathrm{ef}}$ & $0.180^{\mathrm{b}}$ & 0.003 \\
\hline $\mathrm{P} 2$ & $0.229^{\mathrm{a}}$ & $0.195^{\text {bce }}$ & $0.205^{\mathrm{b}}$ & $0.197^{\mathrm{bc}}$ & $0.206^{\mathrm{a}}$ & 0.003 \\
\hline P3 & $0.203^{\mathrm{b}}$ & $0.231^{\mathrm{a}}$ & $0.202^{b}$ & $0.225^{\mathrm{a}}$ & $0.215^{\mathrm{a}}$ & 0.003 \\
\hline Mean & 0.201 & 0.203 & 0.197 & 0.201 & & \\
\hline SEM & 0.004 & 0.004 & 0.004 & 0.004 & & \\
\hline
\end{tabular}

1 Different letters indicate significant differences at $\mathrm{p}<0.05$

Table 6. Effect of interaction between probiotic and rations on relative total gain (\%)

\begin{tabular}{|c|c|c|c|c|c|c|}
\hline & \multicolumn{4}{|c|}{ Total gain/initial weight } & \multirow[b]{2}{*}{ Mean } & \multirow[b]{2}{*}{ SEM } \\
\hline & R1 & $\mathbf{R 2}$ & $\mathbf{R 3}$ & R4 & & \\
\hline P1 & $23.57^{\mathrm{e}}$ & $25.02^{\mathrm{de}}$ & $25.34^{\text {cde }}$ & $25.14^{\mathrm{de}}$ & $24.77^{\mathrm{b}}$ & 0.66 \\
\hline $\mathrm{P} 2$ & $31.19^{a}$ & $26.47^{\mathrm{bcd}}$ & $28.47^{\mathrm{b}}$ & $26.79^{\text {bcd }}$ & $28.23^{\mathrm{a}}$ & 0.66 \\
\hline P3 & $26.42^{\text {bcd }}$ & $31.64^{\mathrm{a}}$ & $27.88^{\mathrm{bc}}$ & $31.18^{\mathrm{a}}$ & $29.28^{\mathrm{a}}$ & 0.66 \\
\hline Mean & 27.06 & 27.71 & 27.23 & 27.71 & & \\
\hline SEM & 0.76 & 0.76 & 0.76 & 0.76 & & \\
\hline
\end{tabular}

1 R1: ration 1, R2: ration 2, $\mathrm{R} 3$ : ration 3, $\mathrm{R} 4$ : ration 4, P1: without probiotic, P2: ZAD, P3:ZAD+ICEC

2 Different letters indicate significant differences at $\mathrm{p}<0.05$

in Table 4 and 5 respectively. results indicated that where groups treated with $\mathrm{P} 2$ and $\mathrm{P} 3$ recorded the highest values compared with untreated groups (P1). This increase may be due to the positive effect of probiotics on ration fibers by improving their chemical composition, components of cell walls, digestibility, nutritional value and the feed efficiency in rations. These results were in agreement with Salem et al (2011). In addition, these results are compatible with Abdeltawab and Khattab (2018) who reported that addition of probiotics to PKC increases its nutritive value and effect positively on nutrient content analysis, nutrient digestibility, whereas, highly content of the cell wall of PKC consists of non-starch polysaccharides, this content reduces digestibility of its nutrients.

Replacement of yellow corn with PKC improve average daily gain in lambs, this improvement increased with the addition of ZAD by $6.7 \%(0.195$ vs. $0.182 \mathrm{~g} / \mathrm{d})$, while addition of ZAD and ICEC-Trol together increased ADG by $21 \%(0.231$ vs. $0.182 \mathrm{~g} / \mathrm{d})$. On the other hand, replacement of sunflower meal with PKC increase ADG by $7.6 \%$ with addition of ZAD (0.197 vs. 0.182) and $19.1 \%$ with addition of ZAD and ICEC-Trol ( 0.225 vs. $0.182 \mathrm{~g} / \mathrm{d}$ ). While using PKC as a source of protein and energy together resulting in a 
smaller increase by replacing them separately (10.7\% for ZAD and $9.4 \%$ for ZAD and ICECTrol).

These results are in agreement with Hakim et al (2020) who reported that bacterial fermentation with lactic acid bacteria and enzymatic fermentation have the capability to improve the (apparent metabolizable energy) AME of PKC. Both enzymatic and bacterial fermentation improved the $\mathrm{CP}$ digestibility. Only bacterial fermentation improved the amino acids digestibility significantly when compared with untreated PKC.

\subsection{Effect of treatments on some blood pa- rameters}

Statistical analysis showed (Table 7) no significant interaction effect on Albumin, Globulin and A/G ratio. Either between (probiotic and ration) $(\mathrm{P} * \mathrm{R})$, probiotic and sampling time $\left(\mathrm{P}^{*} \mathrm{~T}\right)$, (Ration and sampling time) $(\mathrm{R} * \mathrm{~T})$ or sampling time, Probiotic, Ration) $(\mathrm{T} * \mathrm{P} * \mathrm{R})(\mathrm{p}<0.05)$.

\subsubsection{Effect of treatments on serum proteins}

Data in Table 8 showed that serum albumin was not affected by adding probiotic to the diet. On the other hand, globulin concentration was lower for T3 $(3.56 \mathrm{~g} / \mathrm{dl})$ when compared with $\mathrm{P} 1$ and $\mathrm{P} 2(4.23$ and $4.21 \mathrm{~g} / \mathrm{dl})$ respectively. Ratio between albumin and globulin (A/G ratio) increased with P3 (0.95) compared with (P1\&P2) $(0.79,0.78$, respectively).

Data in Table 9 showed that serum Albumin was decreased by adding PKC to the diet (values in R2, R3, R4 were 3.12, 3.10, 3.09 $\mathrm{g} / \mathrm{dl}$, respectively), with no significant differences. Serum albumin was the highest for the control diet (R1s value was $3.30 \mathrm{~g} / \mathrm{dl}$ ). Serum globulin was higher with R2 and R3 (4.30, $4.19 \mathrm{~g} / \mathrm{dl}$, respectively) than $\mathrm{R} 1(3.75 \mathrm{~g} / \mathrm{dl})$ and R4 (3.76 g /dl). Albumin /Globulin Ratio (A/G) Ratio was higher for R1 (0.93) than R2, R3 and R4 (0.77, 0.79 and 0.87 respectively).
Data in Table 10 showed that serum Albumin was higher when blood was sampled before feeding T1 $(3.47 \mathrm{~g} / \mathrm{dl})$ than sampling ( $3 \mathrm{hr}$ after feeding) $\mathrm{T} 2(3.26 \mathrm{~g} / \mathrm{dl})$ and $(6 \mathrm{hr}$ after feeding) T3 $(2.73 \mathrm{~g} / \mathrm{dl})$. On the other hand, globulin was the highest $4.41 \mathrm{~g} / \mathrm{dl}$ for T3 compared with T1 and T2 (3.81, $3.78 \mathrm{~g} / \mathrm{dl}$, respectively). Ratio between albumin and globulin was higher for $\mathrm{T} 1$ and $\mathrm{T} 2(0.95,0.92$, respectively) than T3 (0.65).

\subsubsection{Effect of interaction between Ration and Probiotic on serum parameters in lambs}

Data in Table 11 showed the effect of interaction between rations and probiotics on serum calcium, phosphorus, glucose, creatinine and total protein. Results indicated that serum calcium was the highest for ration 4 with treatment $2(\mathrm{R} 4 * \mathrm{P} 2: 11.19 \mathrm{mg} / \mathrm{dl})$, while it was the lowest with ration 1 with treatment $2(\mathrm{R} 1 * \mathrm{P} 2$ : $9.82 \mathrm{mg} / \mathrm{dl})$. Serum phosphorus was the highest with R3*P1 $(9.35 \mathrm{mg} / \mathrm{dl})$ and lowest for $\mathrm{R} 2 * \mathrm{P} 2(8.47 \mathrm{mg} / \mathrm{dl})$. Serum glucose was the highest with R3* P2 $(50.69 \mathrm{mg} / \mathrm{dl})$ and the lowest with R3*P3 (46.43 mg/dl).Serum creatinine was the highest with R1*P1 $(1.21 \mathrm{mg} / \mathrm{dl})$ and the lowest with $\mathrm{R} 4 * \mathrm{P} 3(0.95 \mathrm{mg} / \mathrm{dl})$.Serum total protein was the highest with $\mathrm{R} 2 * \mathrm{P} 2$ $(7.89 \mathrm{~g} / \mathrm{dl})$ and the lowest with R4 * P3 (6.50 $\mathrm{g} / \mathrm{dl})$.

\subsubsection{Effect of interaction between Ration and sampling time on serum Phosphorus and Glucose in lambs}

Data in Table 12 showed the effect of interaction between rations and sampling time on serum Phosphorus and Glucose in lambs results indicated that serum phosphorus was the highest for R3 after (6 hrs of sampling 9.56 $\mathrm{mg} / \mathrm{dl}$ ) and the lowest with R2 after (6hrs with $8.36 \mathrm{mg} / \mathrm{dl}$ ) serum glucose was the highest for R2 and R3 after (6hrs of feeding) and the lowest for all the experimental Rations before feeding (R1, R2, R3, R4 with values $27.11,25.96,27.68,25.32 \mathrm{mg} / \mathrm{dl}$, respectively). 

of Growing Barki Lambs

Table 7. Significance of main effect and interaction on blood parameters $(\mathrm{p}<0.05)$

\begin{tabular}{|c|c|c|c|c|c|c|c|}
\hline \multirow{2}{*}{ Analysis } & \multicolumn{4}{|c|}{ Interaction } & \multicolumn{3}{c|}{ Main Effect } \\
\cline { 2 - 8 } & $\mathbf{R} * \mathbf{P}$ & $\mathbf{R} * \mathbf{T}$ & $\mathbf{P} * \mathbf{T}$ & $\mathbf{P} * \mathbf{R} * \mathbf{T}$ & $\mathbf{R}$ & $\mathbf{P}$ & $\mathbf{T}$ \\
\hline Glucose & $\mathrm{S}$ & $\mathrm{S}$ & $\mathrm{N}$ & $\mathrm{N}$ & $\mathrm{N}$ & $\mathrm{N}$ & $\mathrm{S}$ \\
\hline Calcium & $\mathrm{S}$ & $\mathrm{N}$ & $\mathrm{N}$ & $\mathrm{N}$ & $\mathrm{S}$ & $\mathrm{S}$ & $\mathrm{S}$ \\
\hline Phosphorus & $\mathrm{S}$ & $\mathrm{S}$ & $\mathrm{N}$ & $\mathrm{N}$ & $\mathrm{S}$ & $\mathrm{N}$ & $\mathrm{S}$ \\
\hline Creatinine & $\mathrm{S}$ & $\mathrm{N}$ & $\mathrm{N}$ & $\mathrm{N}$ & $\mathrm{S}$ & $\mathrm{S}$ & $\mathrm{Ns}$ \\
\hline TP & $\mathrm{S}$ & $\mathrm{N}$ & $\mathrm{N}$ & $\mathrm{N}$ & $\mathrm{S}$ & $\mathrm{S}$ & $\mathrm{Ns}$ \\
\hline Albumin & $\mathrm{N}$ & $\mathrm{N}$ & $\mathrm{N}$ & $\mathrm{N}$ & $\mathrm{S}$ & $\mathrm{N}$ & $\mathrm{S}$ \\
\hline Globulin & $\mathrm{N}$ & $\mathrm{N}$ & $\mathrm{N}$ & $\mathrm{N}$ & $\mathrm{S}$ & $\mathrm{S}$ & $\mathrm{S}$ \\
\hline A/G Ratio & $\mathrm{N}$ & $\mathrm{N}$ & $\mathrm{N}$ & $\mathrm{N}$ & $\mathrm{S}$ & $\mathrm{S}$ & $\mathrm{S}$ \\
\hline
\end{tabular}

1 R: Ration, P: Probiotic, T: Sampling time, S: significant effect, N: Non-Significant effect

Table 8. Effect of probiotic on some blood parameters

\begin{tabular}{|c|c|c|c|c|c|}
\hline \multirow{2}{*}{ Analysis } & \multicolumn{3}{|c|}{ Probiotic } & \multirow{2}{*}{ \pm SEM } & \multirow{2}{*}{$P$ value } \\
\hline & P1 & $\mathbf{P 2}$ & P3 & & \\
\hline $\operatorname{Albumin}(\mathrm{g} / \mathrm{dl})$ & 3.15 & 3.13 & 3.18 & 0.05 & 0.7446 \\
\hline Globulin(g/dl) & $4.23^{\mathrm{a}}$ & $4.21^{\mathrm{a}}$ & $3.56^{\mathrm{b}}$ & 0.12 & 0.0001 \\
\hline A/G ratio & $0.79^{\mathrm{b}}$ & $0.78^{\mathrm{b}}$ & $0.95^{\mathrm{a}}$ & 0.03 & 0.0015 \\
\hline
\end{tabular}

1 Different letters indicate significant differences at $\mathrm{p}<0.05$

Table 9. Effect of rations on serum proteins in lambs

\begin{tabular}{|c|c|c|c|c|c|c|}
\hline \multirow{2}{*}{ Analysis } & \multicolumn{4}{|c|}{ Ration } & \multirow{2}{*}{$\pm \mathrm{SEM}$} & \multirow{2}{*}{$P$ value } \\
\hline & R1 & $\mathbf{R 2}$ & $\mathbf{R 3}$ & R4 & & \\
\hline $\operatorname{Albumin}(\mathrm{g} / \mathrm{dl})$ & $3.30^{\mathrm{a}}$ & $3.12^{\mathrm{b}}$ & $3.10^{\mathrm{b}}$ & $3.09^{\mathrm{b}}$ & 0.06 & 0.032 \\
\hline Globulin(g/dl) & $3.75^{\mathrm{b}}$ & $4.30^{\mathrm{a}}$ & $4.19^{\mathrm{a}}$ & $3.76^{\mathrm{b}}$ & 0.14 & 0.008 \\
\hline $\mathrm{A} / \mathrm{G}$ ratio & $0.93^{\mathrm{a}}$ & $0.77^{\mathrm{b}}$ & $0.79^{\mathrm{ab}}$ & $0.87^{\mathrm{ab}}$ & 0.04 & 0.0186 \\
\hline
\end{tabular}

1 Different letters indicate significant differences at $\mathrm{p}<0.05$

Table 10. Effect of sampling time on serum parameters in lambs

\begin{tabular}{|c|c|c|c|c|c|}
\hline \multirow{2}{*}{ Analysis } & \multicolumn{3}{|c|}{ Sampling time } & \multirow{2}{*}{ × SEM } & \multirow{2}{*}{ P value } \\
\cline { 2 - 4 } & $\mathbf{0 ~ h r s}$ & After 3 hrs & After 6 hrs & & \\
\hline Albumin $(\mathrm{g} / \mathrm{dl})$ & $3.47^{\mathrm{a}}$ & $3.26^{\mathrm{b}}$ & $2.73^{\mathrm{c}}$ & 0.05 & $<0.0001$ \\
\hline Globulin(g/dl) & $3.81^{\mathrm{b}}$ & $3.78^{\mathrm{b}}$ & $4.41^{\mathrm{a}}$ & 0.12 & 0.0005 \\
\hline A/G ratio & $0.95^{\mathrm{a}}$ & $0.92^{\mathrm{a}}$ & $0.65^{\mathrm{b}}$ & 0.03 & $<0.0001$ \\
\hline
\end{tabular}

1 Different letters indicate significant differences at $\mathrm{p}<0.05$ 
Table 11. Effect of interaction between rations and probiotics on serum parameters in lambs

\begin{tabular}{|c|c|c|c|c|c|c|c|}
\hline \multirow{2}{*}{ Analysis } & \multirow{2}{*}{ Probiotic } & \multicolumn{4}{|c|}{ Ration } & \multirow{2}{*}{ \pm SEM } & \multirow{2}{*}{$P$ value } \\
\hline & & R1 & $\mathrm{R} 2$ & R3 & R4 & & \\
\hline \multirow{3}{*}{$\begin{array}{l}\text { Calcium } \\
(\mathrm{mg} / \mathrm{dl})\end{array}$} & $\mathrm{P} 1$ & $10.92^{\mathrm{abcd}}$ & $8.66^{\mathrm{fg}}$ & $11.07^{\mathrm{ab}}$ & $11.04^{\mathrm{abc}}$ & 0.18 & 0.0003 \\
\hline & $\mathrm{P} 2$ & $9.82^{\mathrm{f}}$ & $8.47^{\mathrm{g}}$ & $10.65^{\text {de }}$ & $11.19^{\mathrm{a}}$ & & \\
\hline & P3 & $10.98^{\mathrm{abcd}}$ & $8.98^{\text {cdef }}$ & $11.11^{\mathrm{ab}}$ & $10.54^{\mathrm{e}}$ & & \\
\hline \multirow{3}{*}{$\begin{array}{c}\text { Phosphorus } \\
\text { (mg/dl) }\end{array}$} & $\mathrm{P} 1$ & $9.19^{a b c}$ & $8.66^{\mathrm{fg}}$ & $9.35^{\mathrm{a}}$ & $8.90^{\text {cdef }}$ & 0.16 & 0.0399 \\
\hline & $\mathrm{P} 2$ & $8.70^{\text {efg }}$ & $8.47^{\mathrm{g}}$ & $9.32^{\mathrm{ab}}$ & $9.14^{\text {abcd }}$ & & \\
\hline & P3 & $9.20^{\mathrm{abc}}$ & $8.98^{\text {cdef }}$ & $9.02^{\text {bcde }}$ & $8.84^{\text {def }}$ & & \\
\hline \multirow{3}{*}{$\begin{array}{l}\text { Glucose } \\
(\mathrm{mg} / \mathrm{dl})\end{array}$} & $\mathrm{P} 1$ & $48.23^{b c}$ & $49.08^{\mathrm{abc}}$ & $48.92^{\mathrm{abc}}$ & $48.28^{\mathrm{bc}}$ & 0.89 & 0.0363 \\
\hline & $\mathrm{P} 2$ & $49.06^{\mathrm{abc}}$ & $47.63^{\mathrm{cd}}$ & $50.69^{a}$ & $48.69^{\mathrm{bc}}$ & & \\
\hline & P3 & $49.01^{\mathrm{abc}}$ & $49.80^{\mathrm{b}}$ & $46.43^{\mathrm{d}}$ & $48.51^{\mathrm{bc}}$ & & \\
\hline \multirow{3}{*}{$\begin{array}{l}\text { Creatinine } \\
(\mathrm{mg} / \mathrm{dl})\end{array}$} & $\mathrm{P} 1$ & $1.21^{\mathrm{a}}$ & $1.03^{\text {def }}$ & $1.11^{\mathrm{bcd}}$ & $1.02^{\mathrm{ef}}$ & 0.04 & 0.0283 \\
\hline & $\mathrm{P} 2$ & $1.06^{\text {cde }}$ & $1.01^{\mathrm{ef}}$ & $1.17^{\mathrm{ab}}$ & $1.06^{\text {cde }}$ & & \\
\hline & P3 & $1.12^{\mathrm{bc}}$ & $1.03^{\text {def }}$ & $0.99^{\mathrm{ef}}$ & $0.95^{\mathrm{f}}$ & & \\
\hline \multirow{3}{*}{$\mathrm{TP}(\mathrm{g} / \mathrm{dl})$} & $\mathrm{P} 1$ & $7.81^{\mathrm{ab}}$ & $7.44^{\mathrm{bcd}}$ & $7.36^{\text {cde }}$ & $6.91^{\mathrm{fg}}$ & 0.22 & 0.0132 \\
\hline & $\mathrm{P} 2$ & $6.68^{\mathrm{fg}}$ & $7.89^{\mathrm{a}}$ & $7.68^{\mathrm{abc}}$ & $7.12^{\text {def }}$ & & \\
\hline & P3 & $6.67^{\mathrm{g}}$ & $6.93^{\mathrm{efg}}$ & $6.84^{\mathrm{fg}}$ & $6.50^{\mathrm{g}}$ & & \\
\hline
\end{tabular}

1 means with different letters are significant different at $\mathrm{p}<0.05$

Table 12. Effect of interaction between rations and sampling time on Phosphorus and Glucose of lambs' blood serum

\begin{tabular}{|c|c|c|c|c|c|c|c|}
\hline \multirow{2}{*}{ Analysis } & \multirow{2}{*}{$\begin{array}{c}\text { Sampling } \\
\text { Time }\end{array}$} & \multicolumn{4}{|c|}{ Ration } & \multirow{2}{*}{ \pm SEM } & \multirow{2}{*}{$P$ value } \\
\hline & & R1 & $\mathbf{R 2}$ & R3 & R4 & & \\
\hline \multirow{3}{*}{$\begin{array}{c}\text { Phosphorus } \\
\text { (mg/dl) }\end{array}$} & $0 \mathrm{hrs}$ & $8.67^{\text {ef }}$ & $8.82^{\mathrm{de}}$ & $8.70^{\mathrm{e}}$ & $8.84^{\mathrm{de}}$ & 0.16 & 0.0074 \\
\hline & After $3 \mathrm{hrs}$ & $9.14^{\mathrm{bcd}}$ & $8.93^{\mathrm{de}}$ & $9.43^{\mathrm{ab}}$ & $9.08^{\mathrm{cd}}$ & & \\
\hline & After $6 \mathrm{hrs}$ & $9.27^{\mathrm{abc}}$ & $8.36^{\mathrm{f}}$ & $9.56^{\mathrm{a}}$ & $8.97^{\text {cde }}$ & & \\
\hline \multirow{3}{*}{$\begin{array}{l}\text { Glucose } \\
(\mathrm{mg} / \mathrm{dl})\end{array}$} & $0 \mathrm{hrs}$ & $27.11^{\mathrm{e}}$ & $25.96^{\mathrm{e}}$ & $27.68^{\mathrm{e}}$ & $25.32^{\mathrm{e}}$ & 0.89 & 0.0030 \\
\hline & After $3 \mathrm{hrs}$ & $53.70^{\mathrm{c}}$ & $51.25^{\mathrm{d}}$ & $51.87^{\mathrm{cd}}$ & $51.22^{\mathrm{d}}$ & & \\
\hline & After $6 \mathrm{hrs}$ & $65.49^{\mathrm{b}}$ & $69.29^{\mathrm{a}}$ & $66.50^{\mathrm{b}}$ & $68.94^{\mathrm{a}}$ & & \\
\hline
\end{tabular}

1 Different letters indicate significant differences at $\mathrm{p}<0.05$

Despite of significant differences in some blood parameters except the levels of serum parameters obtained from experimental lambs were within the normal levels required in the body of lambs for growth and development. Serum total protein and globulin had higher $(\mathrm{P}<0.05)$ values in experimental groups fed probiotic ZAD compared with other groups, these results agreement with Abo-Bakr et al
(2020) the protein levels in diets can improve the resistance to infection, moreover the addition of probiotic (ZAD) to diets improved protein digestibility and provide the supply necessary to serum protein whereas important to immune response through making antibodies (Nandi et al 2007) Serum creatinine level showed slightly differences $(\mathrm{P}<0.05)$ due to percentage of protein in rations. Serum glucose 
showed higher $(\mathrm{P}<0.05)$ level in experimental groups fed ZAD with PKC or traditional ration, this increase may be due to biological effect on fibrous and increase the total sugar available in animal rumen (Abdeltawab and Khattab 2018).

\section{Conclusion}

This study concluded that the addition of PKC as a source of energy or protein in lambs' rations be more effective when using two probiotics. While using one probiotic (ZAD) is enough in traditional rations. We recommended studying effect of PKC as a source of protein and energy with addition of probiotics in dairy rations to evaluate its effect on milk production.

\section{References}

Abdeltawab AM, Khattab MSA (2018) Utilization of PKC as a Ruminant Feed for Animal: A Review. Asian J Biol Sci 11, 157-164.

Abo-Bakr S, Kewan KZ, Afaf Nassar MS, ElShereef A, El-Rayes MAH (2020) Utilization of trimming waste of mandarin trees as feed for small ruminants. 1. Palatability and nutritive valuefor treated vs. untreated wastes and the effect on animal immune status. Int $J$ Adv Res 8, 1161-1179.

Alimon AR (2004) The Nutritive Value of PKC for Animal Feed. Palm Oil Developments 40, 12-14.

Alshelmani MI, Loh TC, Foo HL, Lau WH, Sazili AQ (2014) Biodegradation of Palmkernel cake by cellulolytic and hemicellulolytic bacterial cultures through solid state fermentation. Sci World J 1-852.

Gadekar YP, Shinde AK, Sahoo A, Karim SA (2015) Effect of probiotic supplementation on carcass traits and meat quality of Malpura lambs. The Indian Journal of Small Ruminants 21, 306-310.
Gado H, Salem AZM (2013) Anaerobic enzymes as a new technology in animal feed. In: Abdel Fattah, Z.M.S. (eds.), Nutritional Strategies of Animal Feed Additives. Nova Science Publishers, Inc. pp. 24.

Gado HM (2020) Utilization of anaerobic microbiology to improve animal production. Egyptian J Anim Prod 57, 81-86.

Ganai AM, Sharma T, Dhuria RK (2015) Effect of yeast (Saccharomyces cervevisiae) supplementation on ruminal digestion of bajra (Pennisetumglaucum) straw and bajrastarw based complete feed in vitro. Anim Nutr Feed Techn 15, 145-153.

Ginting PS, Simanihuruk K, Tarigan A, Pond KR (2018) Nutritional Support for Small Ruminant Development Based on Oil Palm Byproducts. WARTAZOA 28, 189-198.

Hakim AH, Zulkifli I, Farjam AS, Awad EA, Abdullah N, Chen WL, Mohamad R (2020) Passage time, apparent metabolisable energy and ileal amino acids digestibility of treated PKC in broilers under the hot and humid tropical climate. Ital J Anim Sci 19, 194-202.

Iqbal Z, Rashid MA, Pasha TN, Bhatti JA (2019) Effect of feeding varying levels of PKC on production performance and blood metabolites of lactating crossbred dairy cattle. J Anim Plant Sci 29, 419-424.

Jaafar MD, Jarvis MC (1992) Mannans of oil Palm kernels. Phytochemistry 31, 463-464.

Kim JE, Ji YK, Ki WL, Hyong JL (2007) Cancer Chemopreventive Effects of Lactic Acid Bacteria. J Microbiol Biotechnol 17, 12271235.

Kum, WH, Zahari, MW (2011) Utilisation of oil Palm by-products as ruminant feed in Malaysia. J oil Palm Res 23,1029-1035.

Marini AM, Daud MJ, Noraini S, Azahan E (2005) Performance of locally isolated microorganism in degrading PKC (PKC) fibre and improving the nutritional value of fermented PKC. J Trop Agric Food Sci 33, 311-319. 
Nnadi PA, Kamalu TN, Onah DN (2007) The effect of dietary protein supplementation on the pathophysiology of Haemonchuscontortus infection in West African Dwarf goats. Vet Parasitol 148, 256- 261.

Roslan MAH, Abdullah N, AbdulMurad NZ, Halmi MIE, Zulkifli I, Mustafa S (2017) Optimisation of extrusion for enhancing the nutritive value of PKC using response surface methodology. Bio Resources 12, 6679-6697.

Saeed OA, Sazili AQ, Akit H, Alimon AR, Mazlan M, Samsudin AA (2018) The Growth Efficiency and Carcass Characteristics of Dorper Sheep Treated by Corn Inclusion as Energy into PKC Based-Diet. Trop Anim Sci J 41, 29-36.

Saenphoom P, Liang JB, Ho YW, Loh TC, Rosfarizan M (2011) Effect of enzyme treatment on chemical composition and production of reducing sugars in Palm (Elaeisguineenis) kernel expeller. Afr J Biotechnol 10, 1537215377.
Salem AZM, El-Adawy M, Gado H, Camacho LM, González-Ronquillo M, Alsersy $\mathrm{H}$, Borhami B (2011) Effect of exogenous enzymes on nutrients digestibility and growth performance in sheep and goats. Tropical and Subtropical Agroecosystems 14, 867-874.

Santos RC, Alves KS, Mezzomo R, Oliveira LRS, Cutrim DO, Gomes DI, Leite GP, Araújo MYS (2016) Performance of feedlot lambs fed PKC-based diets. Trop Anim Health Pro 48, 367-372.

Soren NM, Tripathi MK, Bhatt RS, Karim SA (2013) Effect of yeast supplementation on the growth performance of malpura lambs. Trop Anim Health Pro 45,547-554.

Sue, TT (2004) Quality and Characteristics of Malaysian PKCs/Expellers. Palm oil developments 34, 1-3.

Van Soest PJ, Robertson JB, Lewis BA (1991) Methods for rationary fiber, neutral detergent fiber, and non-starch carbohydrates in relation to animal nutrition. J Dairy Sci 74, 3583-3597. 